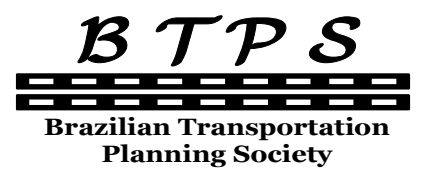

\author{
Journal of Transport Literature \\ Vol. 8, n. 4, pp. 60-81, Oct. 2014 \\ Research Directory
}

JTL|RELIT

www.journal-of-transport-literature.org ISSN 2238-1031

\title{
Evaluating the modal split of overland transportation of general cargo in Brazil using a market share model
}

\author{
[Avaliando a divisão modal do transporte terrestre de carga geral no Brasil \\ usando um modelo de market share] \\ Brunno Santos Gonçalves*, Márcio de Almeida D'Agosto, \\ Ilton Curty Leal Jr., Francisco Gildemir Ferreira da Silva \\ Federal University of Rio de Janeiro - Brazil, Federal University of Rio de Janeiro - Brazil, \\ Federal University of Rio de Janeiro - Brazil, University of Brasília - Brazil
}

Submitted 1 Feb 2013; received in revised form 13 Oct 2013; accepted 3 Nov 2013

\begin{abstract}
This paper presents a methodology developed to evaluate the modal split of land transport of general cargo in Brazil and possible reasons for the prevalence of road transport over rail, using a market share model. No studies were found using the market share model for planning cargo transport, in spite of its generic nature which makes it readily applicable to any market, service, utility or commodity. The methodology was applied in three transport corridors, two groups of general cargo and enabled us to establish that Brazilian rail operations are still uncompetitive in terms of logistics costs when transporting general cargo of high aggregate value. Moreover, transport supply is a determinant factor for the greater use of road transport in Brazil's general cargo transport matrix, and the demand for general cargo transport in Brazil is elastic in relation to this factor. For low aggregate value general cargo (AV1), a 1\% reduction in the gap between road and railway supply leads to an increase in the railway market share of 4.5\% through TC1 (São Paulo - Porto Alegre - São Paulo), 4.9\% through TC2 (Santos - Brasilia - Santos), and 3.3\% through TC3(São Paulo - Rio de Janeiro - São Paulo). For high aggregate value general cargo (AV2), this elasticity was more pronounced. A $1 \%$ reduction in the gap between road and railway transport supply leads to an increase in the railway market share of $4.2 \%$ through TC1, 11.9\% through TC2, and 9.6\% through TC3.
\end{abstract}

Key words: modal split, overland transport of general cargo, market share model, logistics costs, transport supply.

\section{Resumo}

O artigo apresenta metodologia desenvolvida para avaliar a divisão modal do transporte terrestre de carga geral no Brasil e possíveis razões para a prevalência do transporte rodoviário sob o transporte ferroviário, usando um modelo de market share. Não foram encontrados estudos que utilizaram o modelo de market share para o planejamento de transporte de carga, apesar de sua natureza genérica que permite que ele seja aplicado a qualquer mercado, serviço, utilidade ou produto. A metodologia foi aplicada em três corredores de transporte, dois grupos de carga geral e permitiu entender que as operações ferroviárias brasileiras continuam pouco competitivas em termos de custos logísticos para o transporte de carga geral de alto valor agregado. Além disso, constatou-se que a oferta de transporte é um fator determinante para o maior uso do transporte rodoviário na matriz de transporte de carga geral e que a demanda para o transporte de carga geral é elástica a esse fator. Para cargas de baixo valor agregado (VA1), a redução de 1\% no gap entre oferta de transporte rodoviária e ferroviária leva a um aumento de 4,5\% no market share ferroviário no CT1 (São Paulo - Porto Alegre - São Paulo), 4,9\% no CT2 (Santos - Brasília - Santos) e 3,3\% no CT3(São Paulo - Rio de Janeiro - São Paulo). Para cargas de alto valor agregado (VA2) a elasticidade foi mais intensa. A redução de $1 \%$ no gap entre oferta de transporte rodoviária e ferroviária leva a um aumento no market share ferroviário de 4,2\% no CT1, $119 \%$ no CT2 е $9,6 \%$ no СT3.

Palavras-Chave: divisão modal, transporte terrestre de carga geral, modelo de market share, custos logísticos, oferta de transporte.

*Email: brunno@pet.coppe.ufrj.br.

\section{Recommended Citation}

Gonçalves, B., D'Agosto, M., Leal Jr., I. and Silva, F. (2014) Evaluating the modal split of overland transportation of general cargo in Brazil using a market share model. Journal of Transport Literature, vol. 8, n. 4, pp. 60-81.

- JTL/RELIT is a fully electronic, peer-reviewed, open access, international journal focused on emerging transport markets and published by BPTS - Brazilian Transport Planning Society. Website www.journal-of-transport-literature.org. ISSN 2238-1031. 


\section{Introduction}

This paper presents a methodology developed to evaluate the modal split of land transport of general cargo in Brazil and possible reasons for the prevalence of road transport over rail, using a market share model.

Using railways to transport general cargo ${ }^{1}$ in Brazil is still not a prevalent practice. Based on ANTT (2004), ANTT (2011) and ANTAQ (2010), the authors have estimated that railways transported a mere $7.9 \%$ of all Brazilian general cargo in 2011; approximately 25.5 million tons. In contrast, the more popular road transport mode accounted for $85.3 \%$ of cargo transportation in the same year; approximately 275.9 million tons.

Brazilian transport policy guidelines are attempting to establish a more equitable transport matrix with priority being given to the use of more economical and environmentally sustainable transport modes, particularly rail and waterway. The Brazilian government is therefore endeavoring to exploit the comparative advantages of different modes of transport and to integrate and combine their operations to achieve safer and more economical intermodal handling of goods.

Transport studies use various methodologies but new advances have been made in economics that can be useful for transport analysis. Train (2003) indicates that there are three kinds of approaches used in discrete choice models: disaggregate models, aggregate models and those using the dependent variable in the estimation process. The second approach is widely used in market economic structure analysis as, for example, in the works of Basuroy and Nguyen (1998), Nevo (2000) and Train (2003). No studies were found using Nevo's (2000) approach, however, in spite of its generic nature which makes it readily applicable to any market, service, utility or commodity.

\footnotetext{
${ }^{1}$ The main general cargo handled in Brazil comprises construction supplies, steel products, agricultural supplies, processed foods, beverages, electronics, home appliances, and automotive products (ANTT, 2004).
} 
In this context, a methodology based on a market share model has been designed aimed at identifying and measuring factors that influence the greater use of road over rail transport in Brazil. The methodology is a useful tool for sector analysis and for planning cargo transport studies.

Section 1 presents the structured scientific methodology used for analysis, gaining an understanding of the problem and unfolding the research. Section 2 describes the study undertaken to analyze three important Brazilian transport corridors. In Section 3 there is a discussion of the results and lastly, the Section headed "Conclusions" presents the paper's final remarks.

\section{Methodology}

Figure 1 is a schematic illustration of the methodology. Details of the stages are set out in 2.1 to 2.6 .

\subsection{Stage 1 - Initial Settings}

The initial settings in Stage 1 define the scope of the analysis, including the type of cargo and transport modes to be analyzed, a description of a representative sample, and a characterization of the analysis, including level and key aspects.

\subsection{Stage 2 - Attribute Selection}

Stage 2 selects the attributes to be incorporated to the model. They should reflect possible factors determining the use of the modes of transport under analysis and are investigated using research techniques such as literature reviews, document searches, field research, and interviews.

\subsection{Stage 3 - Indicators and Attribute Measurement}

Stage 3 identifies the indicators needed to measure the previously selected attributes. 


\section{Figure 1 - Methodology²}

\begin{tabular}{|c|c|c|c|c|c|}
\hline \multicolumn{2}{|c|}{$\begin{array}{c}\text { STAGE } 1 \\
\text { INITIAL SETTINGS }\end{array}$} & \multicolumn{2}{|c|}{$\begin{array}{c}\text { STAGE2 } \\
\text { ATTRIBUTE SELECTION }\end{array}$} & \multicolumn{2}{|c|}{$\begin{array}{c}\text { STAGE } 3 \\
\text { INDICATORS AND MEASURES OF } \\
\text { ATTRIBUTES } \\
\end{array}$} \\
\hline $\begin{array}{l}\text { Level } 1 \\
\text { Cargo }\end{array}$ & $\begin{array}{l}\text {-Type of cargo to be } \\
\text { analyzed } \\
\text {-Sample }\end{array}$ & \multirow{3}{*}{$\begin{array}{l}\text { Level } 1 \\
\text { Research }\end{array}$} & \multirow{3}{*}{$\begin{array}{l}\text {-Use different research } \\
\text { techniques, such as } \\
\text { literature reviews, } \\
\text { document searches, field } \\
\text { research, and interviews, } \\
\text { to selects the attributes to } \\
\text { be incorporated in the } \\
\text { model }\end{array}$} & \multirow[t]{2}{*}{$\begin{array}{c}\text { Level } 1 \\
\text { Relevant } \\
\text { Parameters }\end{array}$} & \multirow{2}{*}{$\begin{array}{l}\text { - Research to identify the } \\
\text { relevant parameters to } \\
\text { measure the selected } \\
\text { attributes }\end{array}$} \\
\hline $\begin{array}{c}\text { Level } 2 \\
\text { Transport Modes }\end{array}$ & $\begin{array}{l}\text {-Transport modes to } \\
\text { be analyzed } \\
\text {-Sample }\end{array}$ & & & & \\
\hline $\begin{array}{c}\text { Level } 3 \\
\text { Characterization }\end{array}$ & $\begin{array}{l}\text { - Key aspects to be } \\
\text { analyzed } \\
\text { - Level of analysis }\end{array}$ & & & $\begin{array}{l}\text { Level } 2 \\
\text { Indicators and } \\
\text { Measures }\end{array}$ & $\begin{array}{l}\text { - Definition of indicators } \\
\text { and measures of the } \\
\text { selected attributes }\end{array}$ \\
\hline \multicolumn{2}{|c|}{$\begin{array}{l}\text { EXIT } \\
\text { Delimitation of the study universe, and the } \\
\text { basic parameters to guide the subsequent } \\
\text { analysis }\end{array}$} & \multicolumn{2}{|c|}{$\begin{array}{l}\text { EXIT } \\
\begin{array}{l}\text { Selection of the attributes to be incorporated } \\
\text { in the model }\end{array}\end{array}$} & \multicolumn{2}{|c|}{$\begin{array}{l}\text { EXIT } \\
\text { Table with relevant parameters, indicators, } \\
\text { and measures of attributes }\end{array}$} \\
\hline \multicolumn{2}{|c|}{$\begin{array}{c}\text { STAGE6 } \\
\text { SCENARIO ANALYSIS }\end{array}$} & \multicolumn{2}{|c|}{$\begin{array}{l}\text { STAGE5 } \\
\text { MODEL FIT }\end{array}$} & \multicolumn{2}{|c|}{$\begin{array}{c}\text { STAGE } 4 \\
\text { DATA COLLECTION, ESTIMATES AND } \\
\text { ASSESSMENTOF INDICATORS OF } \\
\text { ATTRIBUTES }\end{array}$} \\
\hline \multirow{4}{*}{$\begin{array}{l}\text { Level } 1 \\
\text { Demand } \\
\text { Analysis }\end{array}$} & \multirow{4}{*}{$\begin{array}{l}\text { - Analyzes the impact on } \\
\text { demand stemming from } \\
\text { changes to the parameters } \\
\text { of the transport modes } \\
\text { under consideration, } \\
\text { using the fitted model }\end{array}$} & $\begin{array}{c}\text { Level } 1 \\
\text { Model } \\
\text { Specification }\end{array}$ & $\begin{array}{l}\text { - Research to define the } \\
\text { model specification, and } \\
\text { its functional form }\end{array}$ & \multirow{2}{*}{$\begin{array}{l}\text { Level } 1 \\
\text { Data } \\
\text { Collection }\end{array}$} & \multirow[t]{2}{*}{$\begin{array}{l}\text { - Researches to define the } \\
\text { data collection technique, } \\
\text { and to find the data needed }\end{array}$} \\
\hline & & \multirow[t]{2}{*}{$\begin{array}{c}\text { Level } 2 \\
\text { Calculations }\end{array}$} & \multirow{2}{*}{$\begin{array}{l}\text {-Choice of a software, if } \\
\text { necessary } \\
\text { - Calculations of the } \\
\text { model's coefficients }\end{array}$} & & \\
\hline & & & & \multirow{3}{*}{$\begin{array}{l}\text { Level } 2 \\
\text { Estimates and } \\
\text { Assessment }\end{array}$} & \multirow{3}{*}{$\begin{array}{c}\text { - Estimates and } \\
\text { assessment of indicators of } \\
\text { attributes }\end{array}$} \\
\hline & & \multirow{2}{*}{$\begin{array}{l}\text { Level } 3 \\
\text { Model } \\
\text { Validation }\end{array}$} & \multirow{2}{*}{$\begin{array}{c}\text {-Signal analysis } \\
\text {-Statistical analysis }\end{array}$} & & \\
\hline \multirow{2}{*}{\multicolumn{2}{|c|}{$\begin{array}{l}\text { EXIT } \\
\text { Graphs illustrating the impact on demand } \\
\text { stemming from changes to the parameters of } \\
\text { the transport modes under consideration, } \\
\text { using the fitted model }\end{array}$}} & & & & \\
\hline & & \multicolumn{2}{|c|}{$\begin{array}{c}\text { EXIT } \\
\text { Table with model's coefficients }\end{array}$} & \multicolumn{2}{|c|}{$\begin{array}{l}\text { EXIT } \\
\text { Tables with values of the indicators and } \\
\text { measures }\end{array}$} \\
\hline
\end{tabular}

\subsection{Stage 4 - Data Collection, Estimates, and Assessment of Attribute Indicators}

In Stage 4 data is collected for assessing the attribute indicators. This information is necessary for the subsequent model fitting. The definition of the data collection technique takes into account the availability of data and research resources. When it has been defined, the literature reviews and document searches to obtain the data needed to calculate the indicators are completed. At this stage, the researcher can often come across gaps in the data and estimates are needed to continue the modeling.

Once data have been collected and/or estimated, the attribute indicator values and measurements determined in Stage 3 are calculated and assessed.

\footnotetext{
${ }^{2}$ Source: Developed by the authors based on Leal Jr. and D'Agosto (2011).
} 


\subsection{Stage 5 - Model Fit}

In Stage 5, the modeling technique, the model specification, and its functional form are first defined, and, if necessary, the appropriate software to fit the model is researched. The indicator values measured in Stage 4 provide the data for calculating the model's coefficients.

With the model defined, the signs of the coefficients estimated for each variable are checked for theoretical consistency. Then, statistical analysis is performed to evaluate the significance level of both the model and the variables.

\subsection{Stage 6 - Scenario Analysis}

Stage 6 analyzes the impact on demand stemming from changes to the parameters of the transport modes under consideration, using the fitted model. Changes in demand and the subsequent analysis are the result of a direct application of the model fitted in Stage 5.

Once Stage 6 is complete, the researcher may want to review the model, which is represented in the proposed procedure by means of a link between Stage 6 and Stage 1.

\section{Methodology applied to a study}

In sections 2.1 to 2.6, we apply the methodology illustrated in Figure 1.

\subsection{Stage 1 - Initial Settings}

During this stage, the scope of the Brazilian general cargo industry is analyzed with the aim of developing a model intended for the cargo transport strategic planner. The idea is to fit a modal split model that would consider the key attributes determining the choice between road and railway transport in Brazil, taking into account transfer operations between plants, ports, and distribution centers.

The demand for Brazilian general cargo allocated to the main transport corridors in the country was identified based on official data from the National Overland Transport Board (Agência Nacional de Transportes Terrestres) (ANTT, 2004). This demand was divided into two groups: general cargo of low aggregate value (AV1) and general cargo of high aggregate 
value (AV2). General cargo from the AV1 group has an average value of 25,000.00 R $\$ / T_{E} U^{3}$. The main products are construction supplies, steel products, and agricultural supplies. General cargo from the AV2 group has an average value of 75,000.00 R $\$ / T E U$. The main products are processed foods, beverages, electronics, home appliances, and automotive products.

For the subsequent analysis, the three transport corridors with the greatest flow of general cargo were selected: TC1 (São Paulo - Porto Alegre - São Paulo); TC2 (Santos - Brasilia Santos); and TC3 (São Paulo - Rio de Janeiro - São Paulo). Figure 2 shows the three transport corridors which accounted for approximately $61.6 \%$ of the general cargo handled in Brazil in 2011.

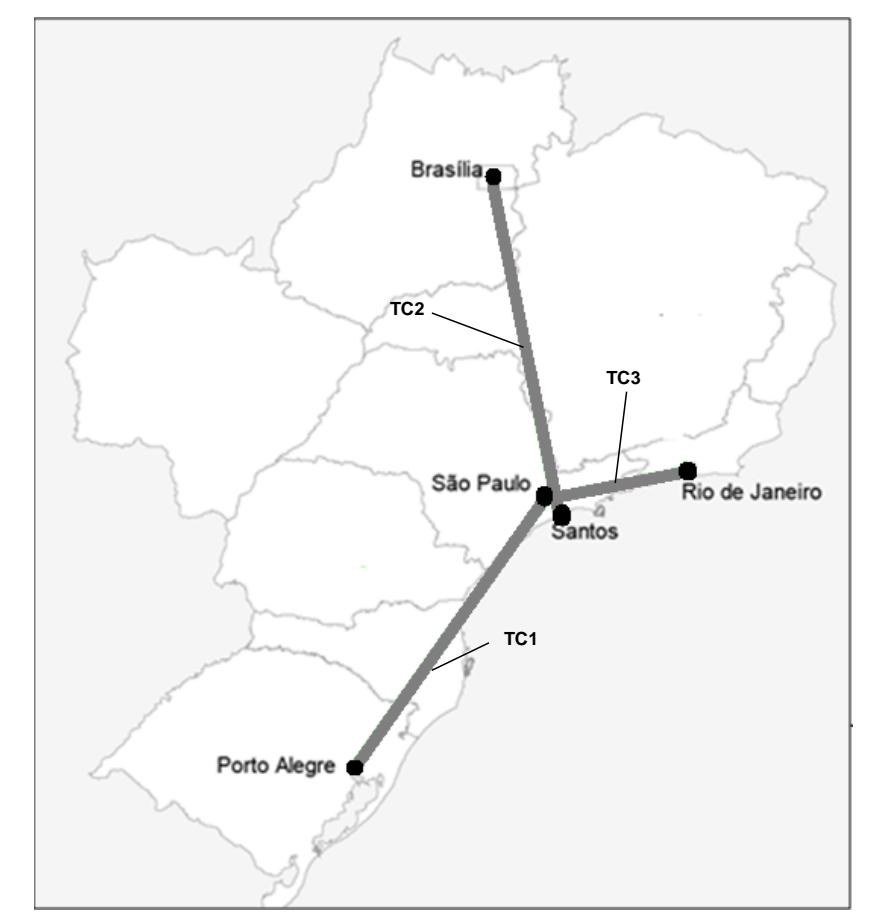

Figure.2 - Selected transport corridors in Brazil ${ }^{4}$

TC1 has an average length of 1,100 km, connecting two highly industrialized regions of Brazil, the South and the Southeast. This corridor transported 81.8 million tons of general cargo in 2011(estimated by authors from ANTT, 2004), about $25.3 \%$ of the total cargo handled that year.

\footnotetext{
${ }^{3}$ TEU - twenty equivalent unit

${ }^{4}$ Source: Developed by the authors.
} 
TC2 has an average length of $700 \mathrm{~km}$ and is an important export and import corridor in Brazil. The corridor connects the state of São Paulo and the regions of Triângulo Mineiro and the Midwest to the Port of Santos. Moreover, it is the main route for the supply and distribution of the Brazilian wholesale industry concentrated in the region of Triângulo Mineiro. This corridor transported 53.0 million tons of general cargo in 2011(estimated by authors from ANTT, 2004), about $16.3 \%$ of the total cargo handled that year.

TC3, which has an average length of $430 \mathrm{~km}$, connects the two largest Brazilian metropolitan areas, namely São Paulo and Rio de Janeiro. Moreover, it is an important transit route for cargo intended for the states of Minas Gerais and Espírito Santo, and for the northeastern and southern regions. This corridor transported 64.4 million tons of general cargo in 2011(estimated by authors from ANTT, 2004), about $19.9 \%$ of the total cargo handled that year.

Railways transported 10.0 million tons of general cargo through these three transport corridors in 2011 (ANTT, 2011); approximately 39.3\% of the total Brazilian general cargo moved by rail in that year. The rail cargo in the three corridors was subdivided as follows: 3.2 million tons through TC1; 3.9 million tons through TC2; and 2.9 million tons through TC3. The cargo transported in these corridors was mainly general cargo of low aggregate value ( 7.7 million tons) and non-containerized general cargo (8.8 million tons).

\subsection{Stage 2 - Attribute Selection}

The literature review summarized in Table 1 was performed to select the attributes to be incorporated in the model. It showed a high incidence of cost-related attributes (32 observations) and service levels (44 observations). Thus, based on the review and prior knowledge of the problem under consideration, it was decided to choose one cost attribute, logistics cost, and one service level attribute, transport supply, as explanatory variables in the model. 
Table 1 - Literature review ${ }^{5}$

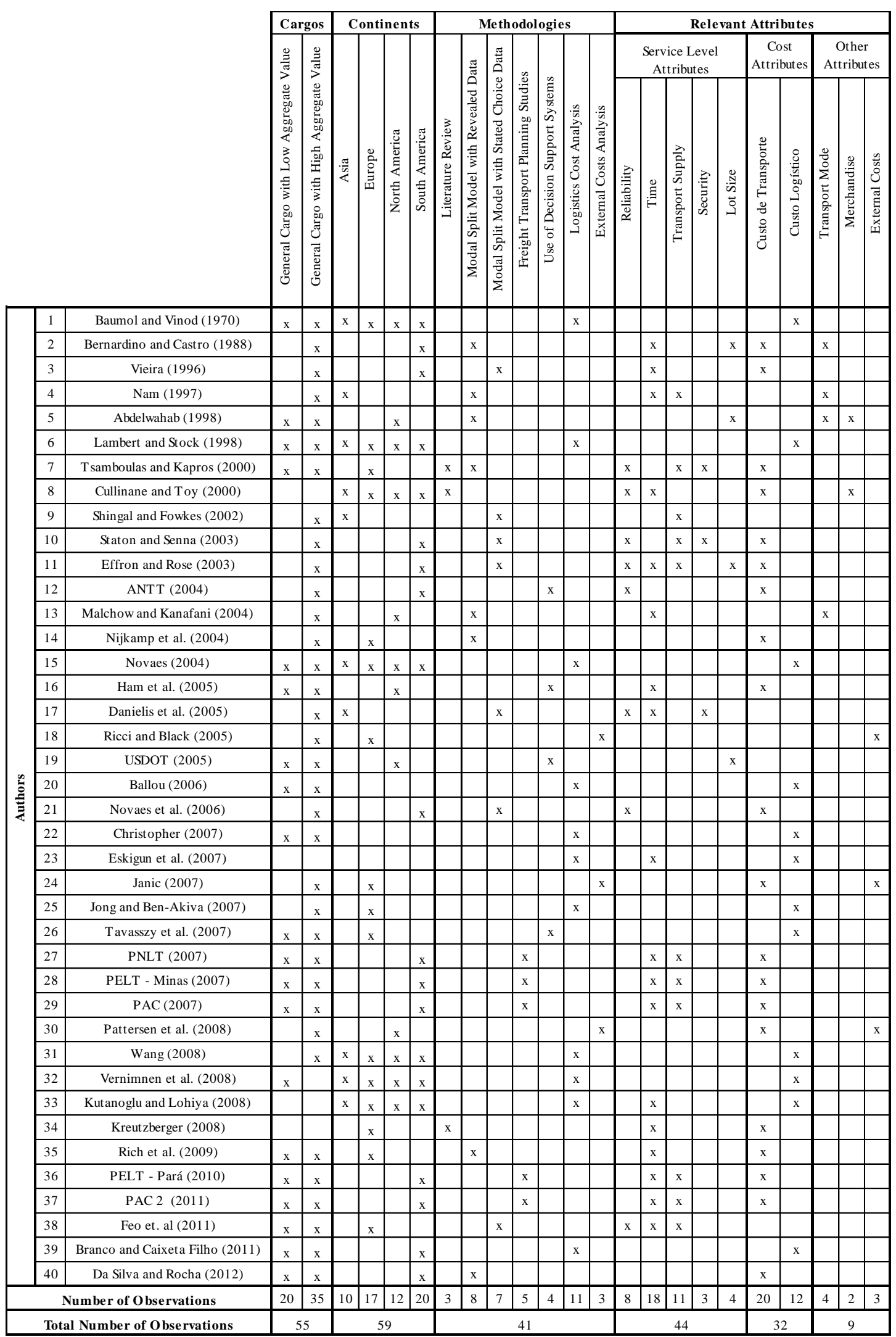

${ }^{5}$ Source: Developed by the authors. 


\subsection{Stage 3 - Attribute Indicators and Measurements}

The Table 2 shows indicators and measurements used to determine the time series of logistics costs and the levels of road and railway transport supply on the selected transport corridors. The measurement of logistics costs was taken to be the sum of the transport, stock, handling, and storage costs between a source and a destination, as proposed by Baumol and Vinod (1970). To measure transport supply, we assumed that the supply of both road and railway transport for general cargo in a specific transport corridor is proportional to the amount of general cargo handled by the transport mode in the corridor in question.

Table 2 - Indicators and measures to determine logistics costs and transport supply ${ }^{6}$

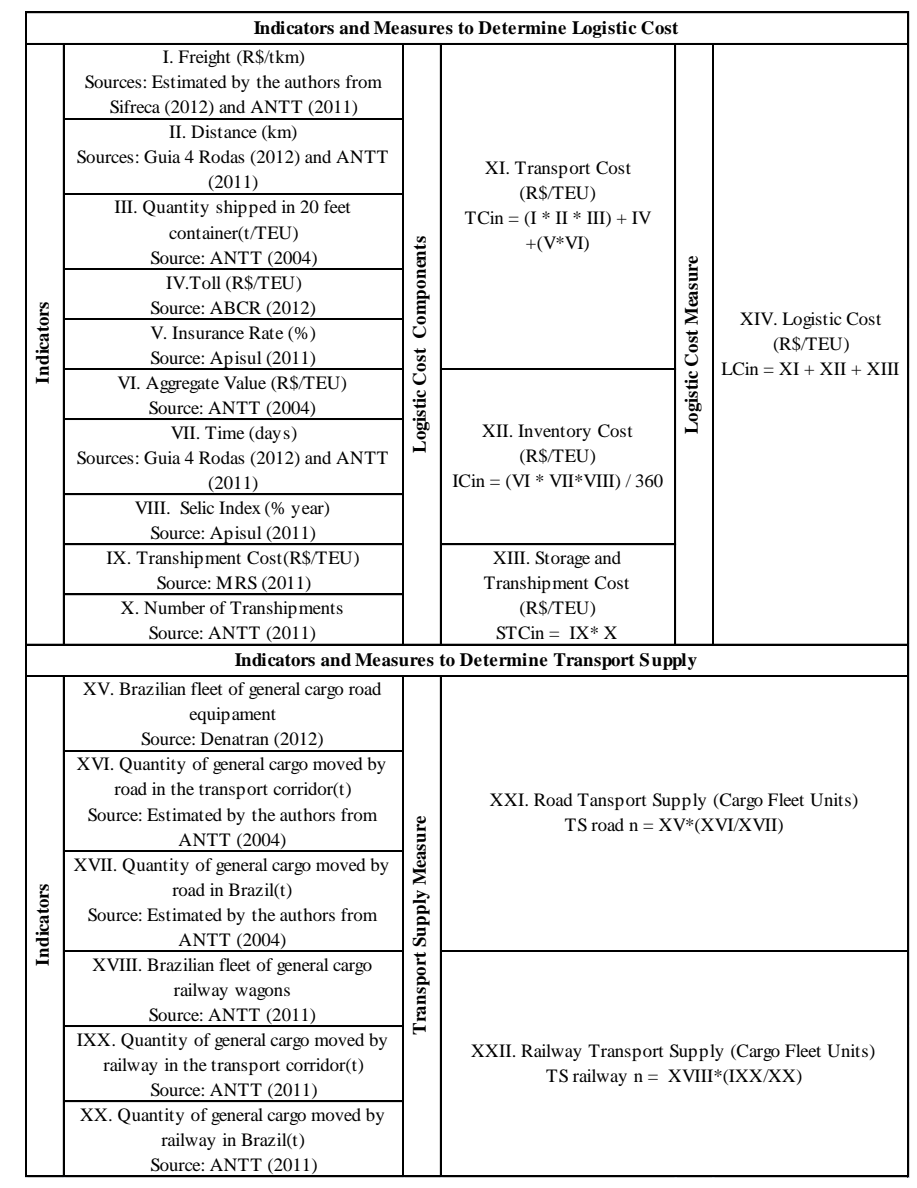

\subsection{Stage 4 - Data Collection, Estimates and Assessment of Attribute Indicators}

During this stage, we collected the required data, representing logistics operations already performed for the transport of general cargo. Table 3 also shows the sources used to gather

\footnotetext{
${ }^{6}$ Source: Developed by the authors.
} 
information about the indicators used to calculate the time series of market share, logistics costs and transport supply statistics. From this collected data, it was possible to estimate and assess the indicators of the selected attributes, thereby creating the database we required to fit the modal split models. This database contained biannual time series of road and railway, market share, logistics costs, and transport supply data.

Table 3 - Database for the fitting of modal split $\operatorname{models}^{7}$

\begin{tabular}{|c|c|c|c|c|c|c|c|c|c|c|c|c|}
\hline \multirow[b]{2}{*}{$\begin{array}{c}\text { Year/ } \\
\text { Semester }\end{array}$} & \multicolumn{6}{|c|}{ TC $1-A V 1$} & \multicolumn{6}{|c|}{ TC $1-A V 2$} \\
\hline & $\begin{array}{l}\text { MS Road } \\
(\%)\end{array}$ & $\begin{array}{l}\text { MS Railway } \\
(\%)\end{array}$ & $\begin{array}{l}\text { LC Road } \\
\text { (R\$/TEU) }\end{array}$ & $\begin{array}{l}\text { LC Railway } \\
\text { (R\$/TEU) }\end{array}$ & $\begin{array}{c}\text { TS Road } \\
\text { (Cargo } \\
\text { Fleet } \\
\text { Units) } \\
\end{array}$ & $\begin{array}{c}\text { TS Railway } \\
\text { (Cargo } \\
\text { Fle et } \\
\text { Units) } \\
\end{array}$ & $\begin{array}{l}\text { MS Road } \\
(\%)\end{array}$ & $\begin{array}{l}\text { MS Railway } \\
(\%)\end{array}$ & $\begin{array}{l}\text { LC Road } \\
\text { (R\$/TEU) }\end{array}$ & $\begin{array}{l}\text { LC Railway } \\
\text { (R\$/TEU) }\end{array}$ & $\begin{array}{c}\text { TS Road } \\
\text { (Cargo } \\
\text { Fleet } \\
\text { Units) } \\
\end{array}$ & $\begin{array}{c}\text { TS Railway } \\
\text { (Cargo } \\
\text { Fle et } \\
\text { Units) } \\
\end{array}$ \\
\hline 200601 & $95.3 \%$ & $4.7 \%$ & 1,405 & 973 & 123,511 & 992 & $96.1 \%$ & $3.9 \%$ & 1,472 & 1,507 & 118,194 & 788 \\
\hline 200602 & $91.9 \%$ & $8.1 \%$ & 1,417 & 981 & 128,7 & 1,302 & $96.9 \%$ & $3.1 \%$ & 1,478 & 1,505 & 123,159 & 478 \\
\hline 200701 & $95.0 \%$ & $5.0 \%$ & 1,444 & 993 & 134,106 & 1,198 & $97.5 \%$ & $2.5 \%$ & 1,502 & 1,498 & 128,332 & 582 \\
\hline 200702 & $94.9 \%$ & $5.1 \%$ & 1,46 & 1,005 & 139,74 & 985 & $95.7 \%$ & $4.3 \%$ & 1,514 & 1,506 & 133,724 & 796 \\
\hline 200801 & $95.2 \%$ & $4.8 \%$ & 1,537 & 1,062 & 145,61 & 999 & $95.8 \%$ & $4.2 \%$ & 1,592 & 1,575 & 139,341 & 825 \\
\hline 200802 & $95.1 \%$ & $4.9 \%$ & 1,631 & 1,134 & 151,727 & 1,055 & $96.3 \%$ & $3.7 \%$ & 1,691 & 1,669 & 145,195 & 769 \\
\hline 200901 & $96.4 \%$ & $3.6 \%$ & 1,653 & 1,149 & 158,101 & 876 & $95.6 \%$ & $4.4 \%$ & 1,706 & 1,672 & 151,294 & 1,005 \\
\hline 200902 & $95.5 \%$ & $4.5 \%$ & 1,635 & 1,133 & 164,742 & 1,015 & $95.7 \%$ & $4.3 \%$ & 1,683 & 1,643 & 157,65 & 934 \\
\hline 201001 & $96.1 \%$ & $3.9 \%$ & 1,63 & 1,135 & 171,663 & 1,042 & $95.9 \%$ & $4.1 \%$ & 1,679 & 1,656 & 164,272 & 1,058 \\
\hline 201002 & $95.3 \%$ & $4.7 \%$ & 1,708 & 1,191 & 178,874 & 1,13 & $95.3 \%$ & $4.7 \%$ & 1,76 & 1,724 & 171,173 & 1,065 \\
\hline 201101 & $96.2 \%$ & $3.8 \%$ & 1,79 & 1,25 & 186,388 & 994 & $95.0 \%$ & $5.0 \%$ & 1,845 & 1,793 & 178,364 & 1,264 \\
\hline 201102 & $95.6 \%$ & $4.4 \%$ & 1,836 & 1,284 & 194,218 & 1,255 & $96.6 \%$ & $3.4 \%$ & 1,891 & 1,832 & 185,856 & 917 \\
\hline \multirow[b]{2}{*}{$\begin{array}{c}\text { Year/ } \\
\text { Semester }\end{array}$} & \multicolumn{6}{|c|}{ TC $2-A V 1$} & \multicolumn{6}{|c|}{ TC $2-A V 2$} \\
\hline & $\begin{array}{l}\text { MS Road } \\
(\%)\end{array}$ & $\begin{array}{l}\text { MS Railway } \\
(\%)\end{array}$ & $\begin{array}{l}\text { LC Road } \\
\text { (R\$/TEU) }\end{array}$ & $\begin{array}{l}\text { LC Railway } \\
\text { (R\$/TEU) }\end{array}$ & $\begin{array}{c}\text { TS Road } \\
\text { (Cargo } \\
\text { Fle et } \\
\text { Units) } \\
\end{array}$ & $\begin{array}{c}\text { TS Railway } \\
\text { (Cargo } \\
\text { Fle et } \\
\text { Units) } \\
\end{array}$ & $\begin{array}{l}\text { MS Road } \\
(\%)\end{array}$ & $\begin{array}{l}\text { MS Railway } \\
(\%)\end{array}$ & $\begin{array}{l}\text { LC Road } \\
\text { (R\$/TEU) }\end{array}$ & $\begin{array}{l}\text { LC Railway } \\
\text { (R\$/TEU) }\end{array}$ & $\begin{array}{c}\text { TS Road } \\
\text { (Cargo } \\
\text { Fle et } \\
\text { Units) } \\
\end{array}$ & $\begin{array}{c}\text { TS Railway } \\
\text { (Cargo } \\
\text { Fle et } \\
\text { Units) } \\
\end{array}$ \\
\hline 200601 & $13.2 \%$ & $86.8 \%$ & 950 & 673 & 13,213 & 1,084 & $97.6 \%$ & $2.4 \%$ & 1,1 & 1,357 & 149,913 & 342 \\
\hline 200602 & $14.6 \%$ & $85.4 \%$ & 957 & 675 & 13,768 & 1,18 & $97.5 \%$ & $2.5 \%$ & 1,107 & 1,364 & 156,21 & 399 \\
\hline 200701 & $13.1 \%$ & $86.9 \%$ & 975 & 688 & 14,347 & 1,204 & $97.8 \%$ & $2.2 \%$ & 1,125 & 1,386 & 162,772 & 347 \\
\hline 200702 & $10.2 \%$ & $89.8 \%$ & 985 & 694 & 14,949 & 1,201 & $97.3 \%$ & $2.7 \%$ & 1,135 & 1,398 & 169,61 & 402 \\
\hline 200801 & $22.6 \%$ & $77.4 \%$ & 1,038 & 735 & 15,577 & 1,162 & $97.6 \%$ & $2.4 \%$ & 1,188 & 1,464 & 176,735 & 404 \\
\hline 200802 & $27.2 \%$ & $72.8 \%$ & 1,103 & 788 & 16,232 & 995 & $97.7 \%$ & $2.3 \%$ & 1,253 & 1,547 & 184,16 & 350 \\
\hline 200901 & $37.8 \%$ & $62.2 \%$ & 1,117 & 795 & 16,914 & 1,014 & $98.3 \%$ & $1.7 \%$ & 1,267 & 1,563 & 191,896 & 314 \\
\hline 200902 & $35.8 \%$ & $64.2 \%$ & 1,103 & 782 & 17,624 & 974 & $97.9 \%$ & $2.1 \%$ & 1,253 & 1,545 & 199,957 & 363 \\
\hline 201001 & $35.5 \%$ & $64.5 \%$ & 1,1 & 781 & 18,364 & 1,031 & $98.4 \%$ & $1.6 \%$ & 1,25 & 1,542 & 208,357 & 297 \\
\hline 201002 & $20.7 \%$ & $79.3 \%$ & 1,154 & 824 & 19,136 & 1,057 & $97.9 \%$ & $2.1 \%$ & 1,304 & 1,609 & 217,11 & 312 \\
\hline 201101 & $28.5 \%$ & $71.5 \%$ & 1,211 & 869 & 19,94 & 1,057 & $98.3 \%$ & $1.7 \%$ & 1,361 & 1,681 & 226,23 & 289 \\
\hline 201102 & $21.2 \%$ & $78.8 \%$ & 1,243 & 893 & 20,777 & 1,157 & $99.0 \%$ & $1.0 \%$ & 1,393 & 1,72 & 235,734 & 161 \\
\hline \multirow[b]{2}{*}{$\begin{array}{c}\text { Year/ } \\
\text { Semester }\end{array}$} & \multicolumn{6}{|c|}{ TC $3-A V 1$} & \multicolumn{6}{|c|}{ TC $3-A V 2$} \\
\hline & $\begin{array}{l}\text { MS Road } \\
(\%)\end{array}$ & $\begin{array}{l}\text { MS Railway } \\
(\%)\end{array}$ & $\begin{array}{l}\text { LC Road } \\
\text { (R\$/TEU) }\end{array}$ & $\begin{array}{c}\text { LC Railway } \\
\text { (R\$/TEU) }\end{array}$ & $\begin{array}{c}\text { TS Road } \\
\text { (Cargo } \\
\text { Fle et } \\
\text { Units) } \\
\end{array}$ & $\begin{array}{l}\text { TS Railway } \\
\text { (Cargo } \\
\text { Fle e t } \\
\text { Units ) } \\
\end{array}$ & $\begin{array}{l}\text { MS Road } \\
(\%)\end{array}$ & $\begin{array}{l}\text { MS Railway } \\
(\%)\end{array}$ & $\begin{array}{l}\text { LC Road } \\
\text { (R\$/TEU) }\end{array}$ & $\begin{array}{l}\text { LC Railway } \\
\text { (R\$/TEU) }\end{array}$ & $\begin{array}{c}\text { TS Road } \\
\text { (Cargo } \\
\text { Fle et } \\
\text { Units) } \\
\end{array}$ & $\begin{array}{c}\text { TS Railway } \\
\text { (Cargo } \\
\text { Fle et } \\
\text { Units) } \\
\end{array}$ \\
\hline 200601 & $93.8 \%$ & $6.2 \%$ & 676 & 343 & 148,455 & 1,573 & $99.2 \%$ & $0.8 \%$ & 724 & 865 & 49,485 & 69 \\
\hline 200602 & $90.9 \%$ & $9.1 \%$ & 682 & 344 & 154,691 & 1,567 & $99.3 \%$ & $0.7 \%$ & 726 & 864 & 51,564 & 41 \\
\hline 200701 & $91.9 \%$ & $8.1 \%$ & 694 & 350 & 161,189 & 1,556 & $99.2 \%$ & $0.8 \%$ & 737 & 872 & 53,73 & 49 \\
\hline 200702 & $92.4 \%$ & $7.6 \%$ & 702 & 353 & 167,96 & 1,533 & $99.0 \%$ & $1.0 \%$ & 742 & 875 & 55,987 & 66 \\
\hline 200801 & $93.0 \%$ & $7.0 \%$ & 738 & 374 & 175,016 & 1,531 & $99.1 \%$ & $0.9 \%$ & 779 & 908 & 58,339 & 65 \\
\hline 200802 & $94.4 \%$ & $5.6 \%$ & 783 & 401 & 182,368 & 1,494 & $98.9 \%$ & $1.1 \%$ & 827 & 952 & 60,789 & 98 \\
\hline 200901 & $95.2 \%$ & $4.8 \%$ & 793 & 404 & 190,029 & 1,52 & $99.3 \%$ & $0, .7 \%$ & 833 & 954 & 63,343 & 70 \\
\hline 200902 & $92.9 \%$ & $7.1 \%$ & 785 & 397 & 198,012 & 1,526 & $99.1 \%$ & $0.9 \%$ & 822 & 941 & 66,004 & 63 \\
\hline 201001 & $94.0 \%$ & $6.0 \%$ & 782 & 396 & 206,33 & 1,551 & $99.6 \%$ & $0.4 \%$ & 820 & 941 & 68,777 & 39 \\
\hline 201002 & $94.5 \%$ & $5.5 \%$ & 819 & 418 & 214,998 & 1,54 & $99.5 \%$ & $0.5 \%$ & 859 & 977 & 71,666 & 50 \\
\hline 201101 & $94.0 \%$ & $6.0 \%$ & 858 & 441 & 224,03 & 1,565 & $99.7 \%$ & $0.3 \%$ & 900 & 1,013 & 74,677 & 26 \\
\hline 201102 & $94.4 \%$ & $5.6 \%$ & 880 & 453 & 233,441 & 1,567 & $99.7 \%$ & $0.3 \%$ & 921 & 1,032 & 77,814 & 26 \\
\hline
\end{tabular}

${ }^{7}$ Legend: TC1 - Transport Corridor 1; TC2 - Transport Corridor 2; TC3 - Transport Corridor 3; MS Road - Road Market Share; MS Railway - Rail Market Share; LC Road - Road Logistics Cost; LC Railway - Rail Logistics Cost; TS Road - Road Transport Supply; TS Railway - Rail Transport Supply. Source: Developed by the authors. 


\subsection{Stage 5 - Model Fit}

Logit Multinominal Modelling - MLM (Equation 1) and variations of it like the Probit Model (Equation 2) were used, both widely diffused and accepted in the academic and transport planning researches as, for example, in the works of Vassallo (2010), Oliveira (2010), Da Silva and De Souza (2013) and Maitra et al. (2013).

$$
P_{i}=\frac{e^{U_{i}}}{\sum_{k=0}^{N} e^{U_{j}}}
$$

Where $P i=$ Probability of alternative $i$ being selected; $U i=$ Utility of alternative $i$; $U j=$ Utility of the $j$ alternatives considered; $e=$ Neper number $(\approx 2.78182) ; N=$ number of alternatives considered.

$$
P_{i}=\frac{1}{1+e^{-U_{i}}}
$$

Where $P i=$ Probability of alternative $i$ being selected; $U i=$ Utility of alternative $i ; e=$ Neper number. The database needed to fit the modal split models can be taken from observational data, the so-called Revealed Preference data or from behavioral research survey data (Declared Preference). According to the type of data, different econometric techniques are used to adjust the utility function coefficients of the modal split model. Models based on Revealed Preference data are usually adjusted using the Ordinary Least Squares method while modal split models based on Declared Preference are adjusted using the Maximum Likelihood technique. Special softwares are available for applying the respective methods.

The market share model, adapted from the researches works of Basuroy and Nguyen (1998), Nevo (2000), and Train (2003), was chosen to fit the modal split models for each of the selected transport corridors and groups of general cargo. As Nevo (2000) has shown, the market share model is developed from an adaptation of logit-type models, assuming that the probability of choosing a transport alternative is equal to the market share of that alternative. Thus, the market share of an alternative is given by Equation 3. 


$$
M S_{i}=\frac{e^{U_{i}}}{\sum_{k=0}^{N=2} e^{U_{j}}}
$$

Where $M S i=$ Market Share of alternative $i ; U i=$ Utility of alternative $i ; U j=$ Utility of alternative $j$; $\mathrm{e}=$ Neper number; $N=$ Number of alternatives. By transforming Equation 1 into its log-linear form, we obtain Equation 4.

$$
\ln M S_{i}-\ln M S_{j}=U_{i}-U_{j}
$$

Adapting Equation 2 to the model developed for the analysis of handling of general cargo in Brazil, as proposed in this paper, we obtain Equation 5.

$$
\ln M S_{R k j t}-\ln M S_{F k j t}=\beta_{0}+\beta_{1}\left(L C_{R k j t}-L C_{F k j t}\right)+\beta_{2}\left(T S_{R k j t}-T S_{F k j t}\right)
$$

Where MSRkjt = Market share of the road alternative in transport corridor $k$, for the transport of general cargo of aggregate value $j$ in semester $t$; MSFkjt $=$ Market share of the rail alternative in transport corridor $k$, for the transport of general cargo of aggregate value $j$ in semester $t$; LCRkjt $=$ Logistics costs of the road alternative in transport corridor $k$, for the transport of general cargo of aggregate value $j$ in semester $t(\mathrm{R} \$ / \mathrm{TEU}) ; L C F k j t=$ Logistics costs of the rail alternative in transport corridor $k$, for the transport of general cargo of aggregate value $j$ in semester $t$ (R\$TEU); TSRkjt =Transport supply of the road alternative in transport corridor $k$, for the transport of general cargo of aggregate value $j$ in semester $t$ (cargo fleet units); TSFkjt $=$ Transport supply of the rail alternative in transport corridor $k$, for the transport of general cargo of aggregate value $j$ in semester $t$ (cargo fleet units); $\beta_{1}, \beta_{2}=$ Coefficients; $\beta_{0}=$ Constant.

The time series data shown in Table 3 was used with the GRETL® software to fit the market share model for each transport corridor and general cargo group.

\subsection{Stage 6 - Scenario Analysis}

To analyze the sensitivity of the coefficients obtained in Stage 5, we calculated the difference between the rail transport market share estimated for the second half of 2011, and the rail 
transport market share for a hypothetical situation resulting from changes in the values of the explanatory variables of the model.

The calculation of the rail transport market share was performed based on Equation 5, considering that the sum of the rail and road market shares is $100 \%$ (Equation 6). From these two equations, we obtained Equation 7, which determines the rail transport market share of a given transport corridor.

$$
\begin{gathered}
M S_{R k j t}+M S_{F k j t}=1 \\
M S_{F k j t}=\frac{1}{e^{\beta_{0}+\beta_{1}\left(L C_{R k j t}-L C_{F k j t}\right)+\beta_{2}\left(T S_{R k l n}-T S_{F k j t}\right)}+1}
\end{gathered}
$$

\section{Results and Discussion}

An analysis of the results obtained at each stage of the applied procedure showed that the handling of general cargo in Brazil is heavily concentrated in the southern and southeastern regions of the country. As a result, the three analyzed transport corridors (results from Stage 1) handle $61.6 \%$ of the total cargo transported. An analysis of the general cargo transported through these corridors by rail showed that the average aggregate value and the level of containerization of these cargos are both low, suggesting that rail logistics costs and rail transport supply are still uncompetitive for goods with higher aggregate value.

The literature review detailed in Table 1 shows that these authors agree with the selection of attributes used to model the modal choice, usually selecting the attributes of cost and service level. However, there is no consensus regarding the most suitable indicators to measure these two attributes. An analysis of the problem proposed in this paper suggests that logistics costs and transport supply are adequate indicators, although, in fact, only transport supply has shown satisfactory statistical results.

The collection of data, data analysis, and measurements performed in Stage 4, as shown in Table 3, showed little variability over time for the observed values of the variables Market Share, Logistics Costs, and Transport Supply for any of the transport corridors and general cargo categories analyzed. 
The average market share analysis of road and rail operations for general cargo categories, during the observation period (Figure 3), showed that, with the exception of low aggregate value general cargo through TC2, the remaining transport corridors have a road market share above $90 \%$. This confirms the greater tendency to use road transport for general cargo in the country. The average rail transport market share of $76.6 \%$ through TC2 for the transportation of general cargo in the AV1 category shows that a significant amount of agricultural and construction supplies is transported by rail through this particular corridor.

Market Share in Transport Corridors by Group of General Cargo

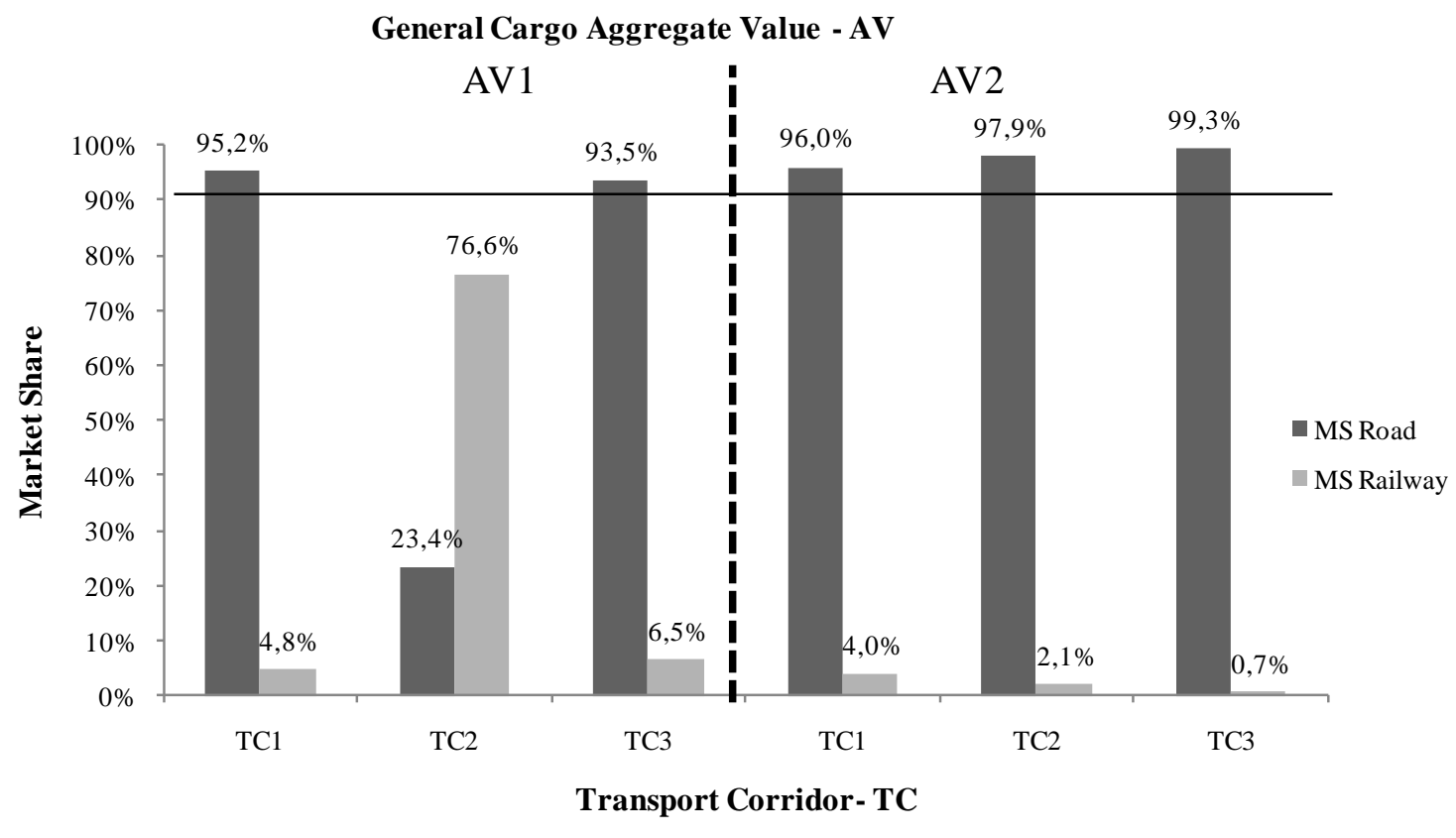

Figure 3 - Market share in transport corridors ${ }^{8}$

An analysis of the average logistics costs of road and rail operations for general cargo categories during the observation period (Figure 4) showed that, for the three transport corridors analyzed, rail logistics costs are competitive when transporting general cargo of low aggregate value (AV1). This finding reflects the fact that some Brazilian rail operations have been designed for door-to-door delivery of these cargo categories, with railway branch lines connecting factories to storage centers, thereby avoiding any additional cargo transfer or road transport costs.

For the high aggregate value general cargo group (AV2), rail transport has a small competitive advantage in terms of logistics costs, but only through TC2, where the average

\footnotetext{
${ }^{8}$ Source: Developed by the authors.
} 
logistics costs of road-railway intermodal operations is $1.2 \%$ lower than the unimodal road operation. This advantage reflects the competitiveness of rail freight for average distances above $600 \mathrm{~km}$, as is the case in this transport corridor. In contrast, the transport figures for these cargos through TC2 and TC3 show that road-railway intermodal transport is still uncompetitive in them. This finding reflects a scenario in which railway fares are still uncompetitive when compared to road freight charges and, furthermore, there are additional cargo transfer and road transport costs associated to the rail operations.

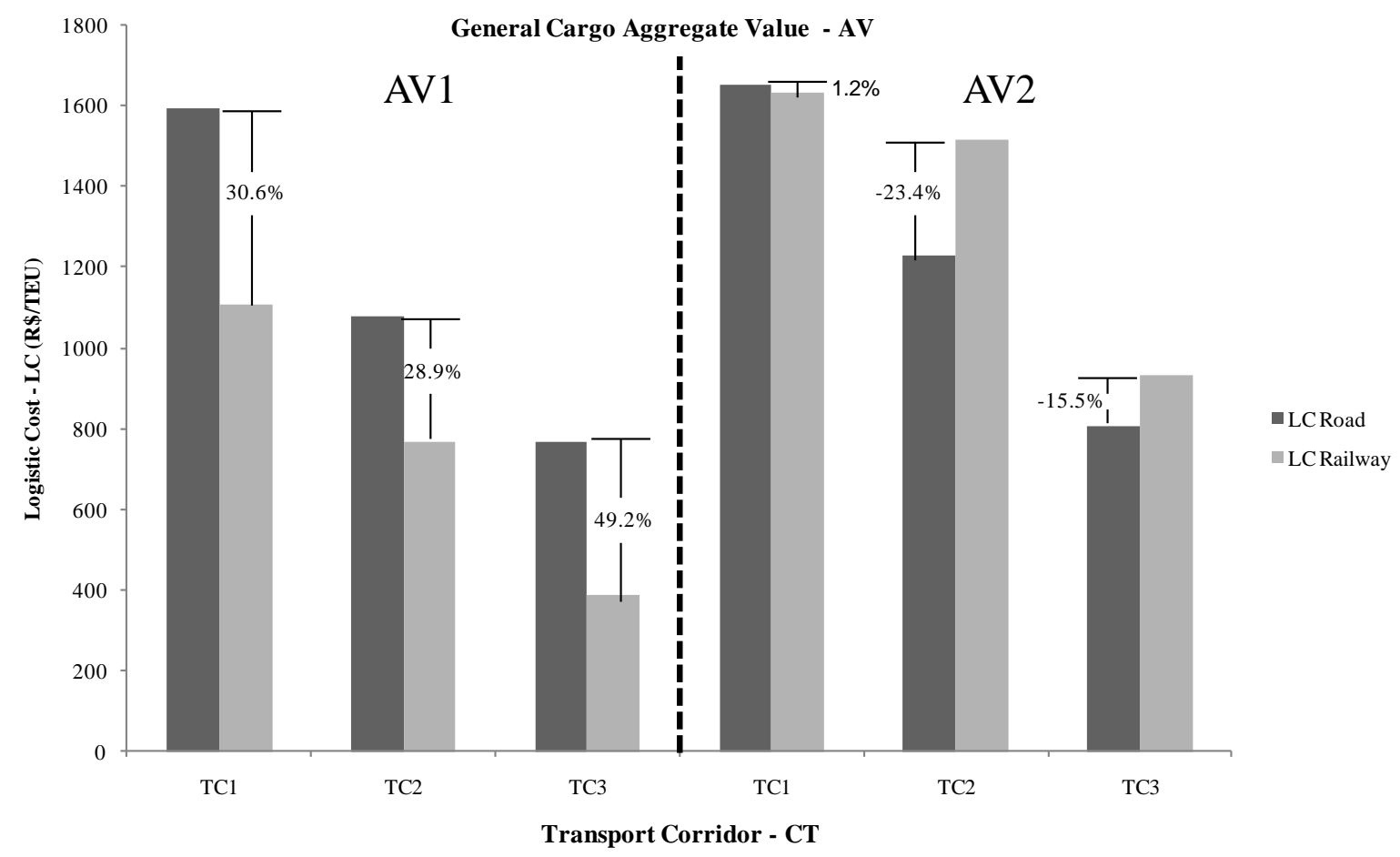

Figure 4 - Comparison of logistics costs ${ }^{9}$

An analysis of the transport supply side (Figure 5) showed that the supply of road transport for general cargo in Brazil has been growing steadily over time, being historically much more significant than the supply of rail transport for this type of cargo which has remained virtually unchanged. As a result, the gap between road and rail transport supply, which was approximately 598,000 cargo fleet units in the first half of 2006, has been gradually growing, reaching 942,700 cargo fleet units in 2011. This represents an increase of $53.6 \%$ during this period. These findings, highlighting the gap between road and rail transport supply, explain the predominance of road transport for general cargo in Brazil.

\footnotetext{
${ }^{9}$ Source: Ibidem.
} 


\section{Transport Supply Evolution}

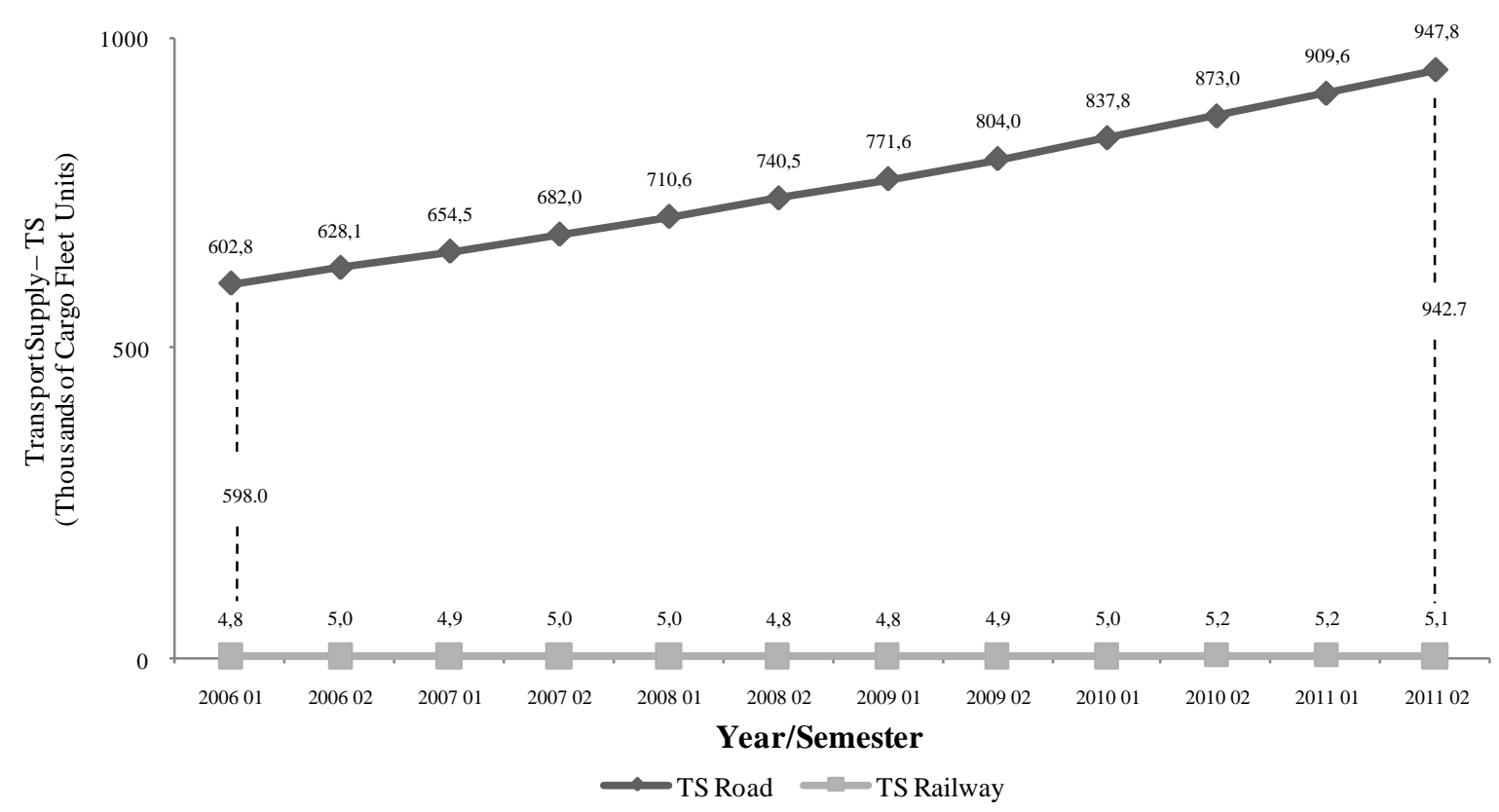

Figure 5 - Evolution of road and railway transport supply in the analyzed transport corridors ${ }^{10}$

An analysis of the fitted models (Table 4) shows that all six models had an adjusted R-Square value above 0.60 . An analysis of the coefficients of the logistics costs variable $(\beta 1)$ showed that these reached a significance level above 90\%, but only for Models III and VI. However, in these models, these coefficients were positive, which is inconsistent with the expected result that the logistics costs variable would be inversely proportional to the market share variable. This may reflect the fact that general cargo demand was evaluated in an aggregated manner, segmented into two groups of general cargo only. Furthermore, the results may be a reflection of the sample size, the lack of data variability and the existence of endogenous variables that were not incorporated to the modeling. Thus, the data analysis performed in Stage 4 did not consider points where there is a migration of general cargo from road to rail as a result of decreases in railway logistics costs.

An analysis of the coefficients of the transport supply variable $(\beta 2)$ showed that these attained statistical significance for all six fitted models. Moreover, in all the models, these coefficients were positive, which is consistent with the expected result that the transport supply variable would be directly proportional to the market share variable. These results show that the

\footnotetext{
${ }^{10}$ Source: Ibidem.
} 
transport supply variable was the key explanatory variable in the fitted models, reflecting the fact that the largest market share for the road transport of general cargo is highly correlated to the large supply of road transport and low supply of railway transport for this market niche.

Table 4 - Statistical results of fitted model ${ }^{11}$

\begin{tabular}{|c|c|ccc|c|}
\hline \multirow{2}{*}{ Models } & \multirow{2}{*}{$\begin{array}{c}\text { Transport } \\
\text { Corridor }\end{array}$} & \multicolumn{3}{|c|}{ Coefficients } & \multirow{2}{*}{ R-Square } \\
\cline { 3 - 5 } Model I & \multirow{2}{*}{ TC1 - AV1 } & $\begin{array}{r}-72.23 \\
(-4.12)\end{array}$ & $\begin{array}{c}7.00 \\
(0.62)\end{array}$ & $\begin{array}{c}74.13 \\
(4.78)\end{array}$ & 0.72 \\
\hline Model II & \multirow{2}{*}{ TC1 - AV2 } & $\begin{array}{r}-78.40 \\
(-4.29)\end{array}$ & $\begin{array}{r}-2.20 \\
(-1.08)\end{array}$ & $\begin{array}{c}82.58 \\
(4.47)\end{array}$ & 0.69 \\
\hline Model III & \multirow{2}{*}{ TC2 - AV1 } & $\begin{array}{r}-41.52 \\
(-2.53)\end{array}$ & $\begin{array}{c}53.08 \\
(1.42)\end{array}$ & $\begin{array}{c}28.46 \\
(3.89)\end{array}$ & 0.66 \\
\hline Model IV & \multirow{2}{*}{ TC2 - AV2 } & $\begin{array}{r}-242.43 \\
(-5.90)\end{array}$ & $\begin{array}{c}21.07 \\
(0.34)\end{array}$ & $\begin{array}{c}252.16 \\
(0.74)\end{array}$ & 0.82 \\
\hline Model V & \multirow{2}{*}{ TC3 - AV1 } & $\begin{array}{c}-45.58 \\
(-2.00)\end{array}$ & $\begin{array}{c}-3.49 \\
(-0.27)\end{array}$ & $\begin{array}{c}50.81 \\
(2.81)\end{array}$ & 0.77 \\
\hline Model VI & \multirow{2}{*}{ TC3- AV2 } & $\begin{array}{c}-437.52 \\
(-4.95)\end{array}$ & $\begin{array}{c}4.25 \\
(1.53)\end{array}$ & $\begin{array}{c}440.04 \\
(5.01)\end{array}$ & 0.82 \\
\hline
\end{tabular}

In Stage 6, we analyzed the changes in the rail transport market share relative to the transport supply variable. ${ }^{12}$ To perform this analysis, the gap between road and rail transport supply was reduced by $1 \%$ in each of the analyzed transport corridors by assuming that the road transport fleet has remained unchanged since the second half of 2011. Changes in the rail transport market share thus obtained are shown in Figure 6.

The analysis shows that for both low aggregate value (AV1) and high aggregate value (AV2) general cargo, demand was elastic relative to fluctuations in the values of the transport supply variable.

For low aggregate value general cargo (AV1), a 1\% reduction in the gap between road and railway supply leads to an increase in the railway market share of $4.5 \%$ through $\mathrm{TC} 1,4.9 \%$ through TC2, and 3.3\% through TC3. For high aggregate value general cargo (AV2), this elasticity was more pronounced. A $1 \%$ reduction in the gap between road and railway transport supply leads to an increase in the railway market share of $4.2 \%$ through TC1, $11.9 \%$ through TC2, and $9.6 \%$ through TC3.

\footnotetext{
${ }^{11}$ Legend: Numbers in brackets represent t-student values. $\beta_{0}$ - constant; $\beta_{1}$ - coefficient of variable Logistics costs; $\beta_{2}$ - coefficient of variable Transport supply. Source: Developed by the authors.

${ }^{12}$ Scenario analysis addressing changes in logistics costs were not performed because this variable's coefficient was not validated in any of the fitted models, either in statistical significance analysis or in signal analysis.
} 
Results show that TC2 is the most attractive corridor for both AV1 and AV2 cargos. For rail transport of the AV1 group, TC2 can potentially increase by 508 tons per cargo fleet unit. For rail transport of the AV2 group, TC2 can potentially increase by 985 tons per cargo fleet unit. These numbers may reflect the high potential of rail transport of general cargo in the AV2 category through TC2.

TC1 has a similar attractiveness for both AV1 and AV2 cargos, with potential to increase by 447 tons per car for AV1 group cargos and 408 tons per car for AVA2 group cargos, respectively. These numbers may stem from the fact that the railway supply for both AV1 and AV2 groups through TC2 are very similar.

TC3 is the least attractive for rail transport of the AV1 group with potential to increase by 357 tons per cargo fleet unit only. However, for AV2 cargos, TC3, as in TC2, is very attractive. Here, TC 3 could potentially increase by 843 tons per cargo fleet unit. This number may also reflect the high potential for the rail transport of general cargo from the AV2 group through TC3.

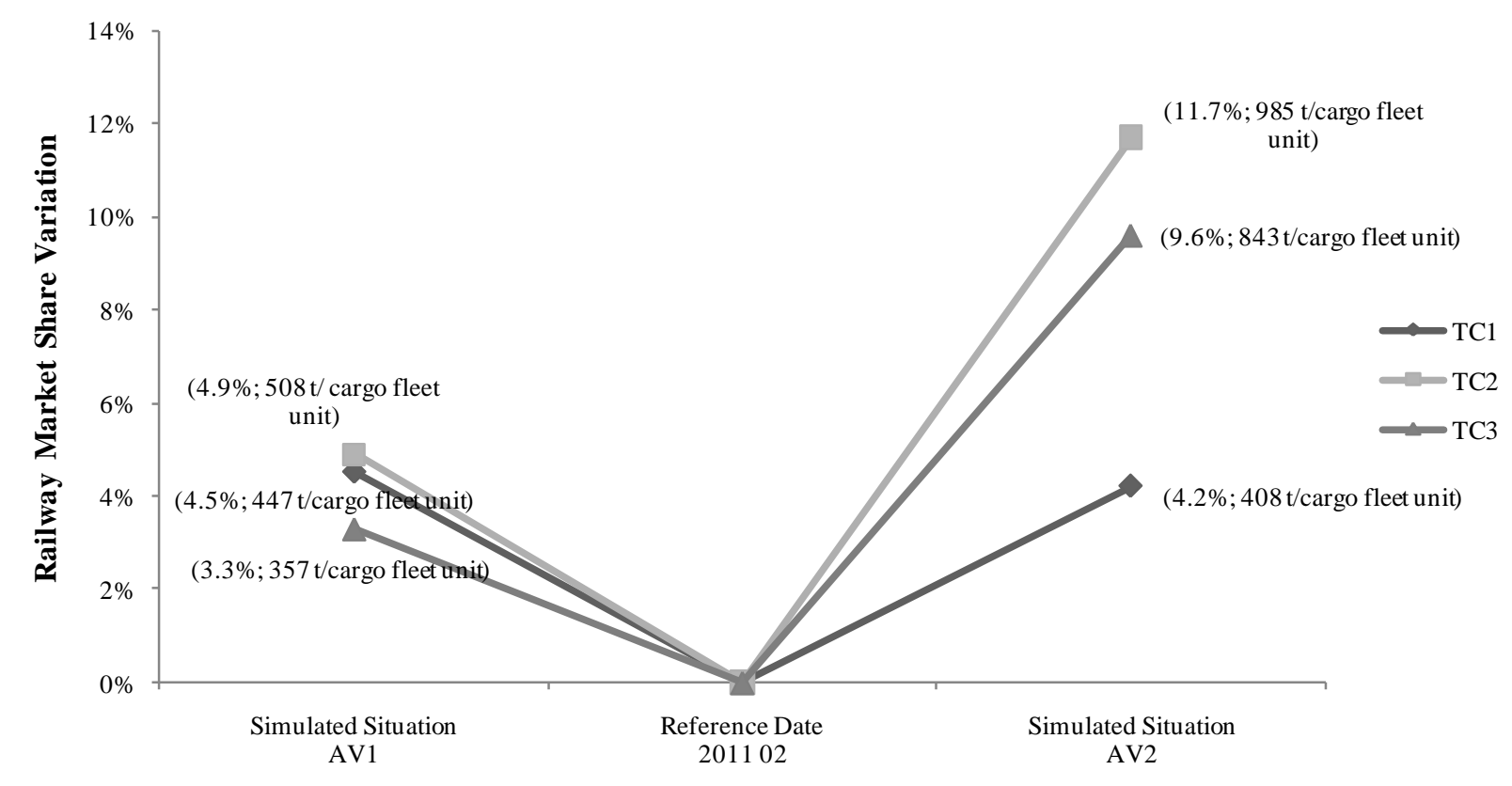

Figure 6 - Sensitivity of transport supply ${ }^{13}$

\footnotetext{
${ }^{13}$ Source: Developed by the authors
} 


\section{Conclusion}

The aim of this paper was to evaluate the modal split of land transport of general cargo in Brazil and possible reasons for the prevalence of road transport over rail transport, using a market share model.

Applying the methodology developed in this study has provided an insight into the land transport of general cargo in Brazil, providing a unique and novel portrait of the recent behavior of demand, logistics costs, and transport supply for this market niche.

Results have shown that the preferential use of road transport, to the detriment of rail transport, for general cargo in Brazil is due to the low competitiveness of the railways in terms of logistics costs for transporting general cargo of higher aggregate value, which leads us to suggest that Brazilian railways are not yet ready for the large-scale transportation of such goods.

In addition, another determining factor for this road transport predominance is the existence of a growing supply of road transport in contrast to the small and virtually unchanged supply of rail transport. Based on the supply elasticity analysis, this scenario is likely to change, should the rail transport supply in Brazil come to be stimulated and promoted.

The major limitations of the developed model were the unavailability of time series data concerning the handling of general cargo on Brazilian roads and railways prior to 2006, and the lack of demand data classified according to a wider range of goods categories. These limitations precluded a more disaggregated analysis of the goods that are part of the scope of general cargo in Brazil.

The methodology presented in this paper is general enough to be applicable to other related research. It is suggested that future studies on the topic should: analyze why the use of railway containers for transporting general cargo in Brazil is so limited; analyze the rail transport offer for general cargo, and investigate the feasibility and impact on demand and on the environment of establishing intermodal logistics operations for the transport of general cargo. 


\section{References}

ABCR (2012) Concessionárias. Work Document - ABCR (consulted in www.abcr.org.br).

Abdelahab, W. M. (1998) Elasticities of mode choice probabilities and market elasticities of demand: evidence from simultaneous mode choice/shipment-size freight transport model. Transportation Research E, 34, n. 4, pp. 257-266.

ANTAQ (2010) Navegação de Interior - Estatística 2010. Work Document - ANTAQ (consulted in www.antaq.gov.br).

ANTT (2004) Logística e Transporte para Produtos de Alto Valor Agregado no Contexto Brasileiro. Work Document - ANTT (unpublished study).

ANTT (2011) SAFF - Sistema de Acompanhamento Ferroviário. Work Document - ANTT (unpublished study).

Apisul (2011) Seguros. Work Document - Apisul (consulted in www.apisul.com.br).

Ballou, R. (2006) Gerenciamento da cadeia de suprimentos: planejamento, organização e logística empresarial. 4. ed., Porto Alegre, Editora Bookman.

Basuroy, S. and Nguyen, D. (1998) Multinomial logit market share models: Equilibrium characteristics and strategic implications. Management Science, vol. 44, n.10, pp. 1396-1408.

Baumol, W. J. and Vinod, H. D. (1970) An Inventrory Theoretic Model of Freight Transport Demand. Management Science, vol.16, pp. 413-421.

Bernadino, A. and Castro, N. (1988) A Escolha de Conteinereização na Exportação de Manufaturados. Pesquisa e Planejamento Econômico, vol. 18, pp. 709 - 740.

Branco, J. E. and Caixeta Filho J. V. (2011) Estimativa da demanda de carga captável pela estrada de Ferro Norte-Sul. Journal of Transport Literature, vol. 5, n. 4, pp. 17-50.

Christopher, M. (2007), Logística e gerenciamento da cadeia de suprimentos: grandes redes que agregam valor. São Paulo, Editora Thomson.

Culliane, K. and Toy, N. (2000) Identifying influential attributes in freight route/mode choice decisions: a content analysis. Transportation Research Part E, vol. 36, pp. 41-53.

Da Silva, F. G. F. and De Souza, S. A. (2013) Estimando valor de tempo de viagem com diferentes fontes de dados utilizando modelos logit. Journal of Transport Literature, vol. 7, n. 4, pp. 107129.

Da Silva, F. and Rocha, C. H. (2012) A demand impact study of southern an southeastern ports in Brazil: An indication of ports competition. Maritime Economics \& Logistics, vol. 14, pp. 204219.

Dannielis, R., Marcuci, E. and Rotaris, L. (2005) Logistics managers_stated preferences for freight service attributes. Transportation Research Part E, vol. 41, pp. 201-215.

Denatran (2012) Estatística. Work Document - Denatran(consulted in www.denatran.gov.br).

Efron, A. and Rose, J. (2003) Truck or Train? A Stated Choice Study on Intermodalism in Argentina. Anais do XVII Congresso de Pesquisa e Ensino em Transporte, Salvador.

Eskigun, E., Uzsoy R., Preckel, P., Beaujon, G., Krishan, S. and Tewl, J. D. (2006) Outbound Supply Chain Network Design with Mode Selection. Published online in www.interscience.wiley.com.

Feo, M., Espino, R. and Garcia, L. (2011) A stated preference analysis of Spanish freight forwarders modal choice on the south-west Europe Motorway of the Sea. Transport Policy, vol. 18, n. 1, pp. 60-67. 
Guia 4 Rodas (2012) Mapas e Rotas. Work Document - Guia 4 Rodas (consulted in www.viajeaqui. abril.com.br/guia4rodas).

Ham, H., Kim, G. and Boyce, D. (2005) Implementation and estimation of a combined model of interregional, multimodal commodity shipments and transportation network flows. Transportation Research Part B, vol. 39, pp. 65-79.

IPEA (2012) Ipea Data. Work Document - IPEA (consulted in www.ipea.gov.br).

Janic, M. (2007) Modelling the full costs of an intermodal and road freight transport network. Transportation Research Part D, vol. 12, pp. 33-44.

Jong, G. and Ben-Akiva (2007) A micro-simulation model of shipment size and transport chain choice. Transportation Research Part B, vol. 41, pp. 950-965.

Kreutzberger, E. (2008). Distance and time in intermodal goods transport networks in Europe: A generic approach. Transportation Research Part A, vol. 42, pp. 973-993.

Kutanoglu, E. and Lohiya, D. (2008) Integrated inventory and transportation mode selecetion: A service parts logistics system. Transportation Research Part E, vol. 44, pp. 665-683.

Lambert, D. and Stock, J. (1998) Strategic logistic management. 3 ed., Boston MA. Irwin.

Leal Jr. I. and D'Agosto, M. (2011) Modal choice evaluation of transport alternatives for exporting bio-ethanol from Brazil. Transportation Research Part D, vol. 16, pp. 201-207.

Maitra, B., Gosh, S., Das, S. and Boltze, M. (2013) Effect of model specification on valuation of travel attributes: a case study of rural feeder service to bus stop. Journal of Transport Literature, vol. 7, n. 2, pp. 8-28.

Malchow, M. B. and KanafiI, A. (2004) A disaggregate analysis of port selection. Transportation Research Part E, vol. 40, pp. 317-337.

MRS (2011) Fale Conosco. Work Document MRS (consulted in www.mrs.com.br).

Nam, K. (1997) A Study on the estimation and aggregation of disaggregate models of mode choice for freght transport. Transportation Research E, vol. 33, n. 3, pp. 223-231.

Nevo, A. (2000) Mergers with Differentiated Products: The Case of the Ready-to-Eat Cereal Industry. The RAND Journal of Economics, vol. 31, n. 3, pp. 395-421.

Nijkamp, P., Reggiani, A. and Tsang, W. (2004) Comparative modelling of interregional transport flows: Applications to multimodal European freight transport. European Journal of Operational Research, vol. 155, pp. 584-602.

Novaes, A. G. (2004) Logística e gerenciamento da cadeia de suprimentos. 2. ed., São Paulo, Editora Campus.

Novaes, A. G. N., Gonçalves, B., Costa, M. B. and Santos, S. (2006) Rodoviário, Ferroviário ou Marítimo de Cabotagem: O Uso da Técnica de Preferência Declarada para Avaliar a Intermodalidade no Brasil. Transportes, vol. XIV, pp. 11-17.

Oliveira, A. V. M. (2010) A alocação de slots em aeroportos congestionados e suas consequências no poder de mercado das companhias aéreas. Journal of Transport Literature, vol. 4, n. 2, pp. 7-49.

PAC (2007) $1^{\circ}$ Balanço do PAC janeiro a abril de 2007. Work Document of Brazilian Government (consulted in www.pac.gov.br)

PAC 2 (2011) Relatório - Lançamento PAC 2. Work Document of Brazilian Government (consulted in www.pac.gov.br).

PELT - Minas (2007) Plano Estratégico de Logística de Transportes. Work Document of Brazilian Government (consulted in www.transportes.mg.gov.br).

PELT - Pará (2010), Programa Estadual de Logística do Estado do Pará. Work Document of Brazilian Government (consulted in www.setran.pa.gov.br). 
Pettersen, Z., Ewing, G. and Haider, M. (2008) The potential for premium-intermodal services to reduce freight $\mathrm{CO} 2$ emissions in the Quebec City-Windsor Corridor. Transportation Research Part D, vol. 13, pp. 1-9.

PNLT (2007) Plano Nacional de Logística \& Transportes - Relatório Executivo. Work Document of Brazilian Government (consulted in www.transportes.gov.br).

Ricci, A. and Black, I. (2005) Measuring the Marginal Social Cost of Transport. Research in Transportation Economics, vol. 14, pp. 245-285

Rich, J., Holmblad, P. M. and Hansen, C. O. (2009) A weighted logit freight mode-choice model. Transportation Research Part E, vol. 45, pp. 1006-1019.

Sifreca (2012) Fretes Rodoviários. Work Document - Sifreca (consulted in www.sifreca.esalq.usp.br).

Syndarma (2010) Estatísticas da Navegação Brasileira. Work Document - SYNDARMA (consulted in www.syndarama.org.br).

Staton, B. and Senna, L. (2003) Aplicação de QFD e Preferência Declarada no Transporte de Cabotagem. Transportes, vol. XI, n. 1.

Shingal, N. and Fowkes, T. (2002) Freight mode choice and adaptive stated preferences. Transportation Research Part E, vol. 38, pp. 367-378.

Swenseth, S. R. and Godfrey, M. R. (2002) Incorporating transportation costs into inventory replenishment decisions. International Journal of Production Economics, vol. 77, pp. 113-130.

Tavasszy, A. L., Van Der Vlist, J. M. and Vam Haselem, J. M. (2007) Freight Transportation System Modelling: Chains, Chains and Chains. Seventh International Special Conference of IFORS: Information Systems in Logistics and Transportation, Gothenburg.

Train, K. (2003) Discret Choice Methods with Simulation. London: Cambridge University.

Tsamboulas, D. A. and Kapros, S. (2000) Decision-Making Process in Intermodal Transportation. Transportation Research Record, vol. 1707, pp. 86-93.

USDOT (2005) Intermodal Transportation and Inventory Cost Model Highway-to-Rail Intermodal: User's Manual. Work Document - USDOT (consulted in www.dot.gov/new/index.htm).

Vassallo, M. D. (2010) Simulação de fusão com variações de qualidade no produto das firmas: aplicação para o caso do code-share Varig-TAM. Journal of Transport Literature, vol. 4, n. 2, pp. 50-100.

Vernimen, B., Dullaert, W., Wlleme, P. and Wltox, F. (2008) Using the inventory-theoretic framework to determine cost-minimizing supply strategies in a stochastic setting. International Journal of Production Economics, vol. 115, pp. 248-259.

Vieira, H. F. (1996) Uma visão empresarial do processo de exportação de produtos conteinerizados catarinenses e a análise do nível de serviço logístico. Dissertation (Master in Industrial Engeneering), Universidade Federal de Santa Catariana, Florianópolis.

Wang, M. (2008) Uncertain Analysis of Inventory Theoretic Model for Freight Mode Choice. International Conference on Intelligent Computation Technology and Automation, Madrid. 